DOI: $10.20472 /$ IAC.2017.032.005

\author{
ROXANA LOREDANA AVRAM \\ WEST UNIVERSITY OF TIMISOARA, Romania
}

ALEXANDRU BUGLEA

WEST UNIVERSITY OF TIMISOARA, Romania

ALEXANDRU AVRAM

WEST UNIVERSITY OF TIMISOARA, Romania

\title{
THE IMPACT OF CORPORATE GOVERNANCE ON THE COMPANY'S PERFORMANCE
}

\begin{abstract}
:
In our paper we have developed an index for measuring the corporate governance in the Romanian economy based on the corporate governance code of Bucharest Stock Exchange. Corporate governance represents measures and policies through which a company achieves its settled objectives. In the first part of our research we have constructed the index by a questionare that was aplied to major Romanian companies, that were split into four major sectors: banking, oil \& gas, automotive and agriculture. In the second part of our research we have measured our index' impact on performance taking into consideration ROA, size and liquidity, by using a panel VAR for each sector.
\end{abstract}

\section{Keywords:}

corporate governance, performance, index of corporate governance

JEL Classification: G34, 016 


\section{Introduction}

Corporate governance is a "blueprint" whereby companies are internally managed and supervised by the board of directors in order to protect the interests of all parties involved.

The financial crises that have emerged over the years globally, the spectacular bankruptcies of large corporations or financial institutions, as well as the discrepancy between executives' remuneration and company's size, have demonstrated over the years that implementing corporate governance is not just a fad, but a way of survival, a strategy to improve the performance of companies. Besides the fact that corporate governance contributes to increase the performance, it also requires transparency on all transactions within the company, as well as on relations with the investors, creditors, customers and suppliers. Additionally, the implementation of corporate governance contributes to limiting the abuse of power from the inside on the company's resources, by providing management monitoring tools to ensure that they fully follow the organization's goals, not their own benefits.

Over the years, the literature has confirmed the importance of corporate governance, substantial efforts being made in the developed countries to implement it. Therefore, more than 180 corporate governance codes have been implemented globally, which have been characterized by a high level of convergence in terms of their content (Aguilera, Cuervo Cazurra, 2004). Corporate governance codes have emerged in developed countries, but the recommendations of best corporate governance practices have been disseminated beyond their borders. In order for the principles of good corporate governance to be respected and also to have a positive influence on the economy in all countries, it is absolutely necessary to have a set of democratic institutions of the market economy.

In the case study presented below, we aimed to study the impact of the corporate governance index on some sectors in Romania through a Vector Auto Regressive (VAR), taking into account the causal relationship between performance and corporate governance, and more specifically the introduction of a set of principles stipulated in the Corporate Governance Code of the Bucharest Stock Exchange, by taking into consideration the specificities of the field analyzed.

\section{Synthesis of literature on corporate governance in emerging economies}

In this section, we provide a brief review of the theoretical and empirical literature on the implementation of corporate governance principles in emerging economies. The literature on the subject is extremely vast. The study by Black (2001, pp. 89-108) on a sample of Russian firms for 1999 showed a strong correlation between a corporate governance index and market value. Similarly, for 1999-2004, an important economic and statistical correlation between governance and market value was identified (Black et al., 2006, pp. 
361-379). In the financial field, however, there are only a few significant, but weak from economic perspective, relations between the quality of governance and operational performance if these two variables are measured over the same period; bond strength decreases even more if the operational performance is measured in a subsequent period (Love, Rachinsky, 2007, p. 17).

Doidge, Karolyi and Stulz (2004) argue that when financial development is weak, incentives to improve corporate governance are low because external financing and better governance mechanisms are becoming costly.

Gillan, Hartzell and Stark (2003) analyze the choosing of corporate governance at firm and industry level in the US. From a global perspective, the situation in the US is unique due to the active struggle for corporate governance control, the high level of financial market development, the complexity of the property concept, and relatively strong investor protection laws.

Durnev and Kim (2005) discover that governance is positively linked to growth opportunities, the need of company for external financing and the concentration of cash flows (ownership concentration). By the means of a series of simultaneous equations, using variables such as governance ratios and firm value, the same authors conclude that firms with better quality of investment opportunities and greater need for external funding are choosing better governance, leading to a better evaluation.

When data on company governance is available, panel models can be estimated, greatly reducing potential endogenous problems. We have taken this into consideration during the case study, a fact identified by Black, Kim, Jang and Park (2005) who analyzed the governance of Korean companies between 1998 and 2003 by using panel data. Therefore, they conclude that corporate governance is an important factor in explaining the value of a firm in Korea. Black, Love, and Rachinsky (2005) estimate panel-type models with fixed and random effects for a sample of Russian firms during 1999-2005 and find that governance can be used to estimate the value of a firm.

We can observe a multitude of studies addressing the causality between corporate governance and the value of firms, a study worth mentioning being made by the authors Da Silva, Luiz, Pereira (2005), based on which we started to design a Corporate Governance Index applicable to Romanian economic companies.

In the research performed by the author Kouwenberg (2006), a cross-regression was used on 320 listed companies in Thailand, measuring the implementation of the principles of good governance in the Thai code by each of the 320 listed companies, based of the obligation specified in the conformity declarations from 2002. Thus, an increase in the standard deviation of the code adoption index was observed, in correlation with a $10 \%$ increase in the company's average value (Tobin's $Q$ ) over the three-year period for the code's adoption while controlling the company-specific factors and the effects of the 
industry. The identified relationship is considered very significant and was not present before the code was introduced in 2001, suggesting a causal link between code adoption and firm value.

Reddy, Locke and Scrimgeour (2010) concluded that the new corporate governance recommendations set out by the New Zealand financial authorities in the 2004 corporate governance code had a positive and lasting impact on the financial performance of listed companies.

Grove, Patelli, Victoravich, and Xu (2011) have identified in their research that the quality of corporate governance in the US banking system has a greater impact on financial performance than the quality and conditions of indebtedness, an aspect that we have taken into consideration as well in our case study below.

A relevant study (Alley, Adebayo, Oligbi, 2016) starts from the mutual causality between corporate governance and performance, analyzing the link between the two concepts through a VAR and VEC, raising by the means of this methodology the problem of the lack of studies between performance and governance. Starting from the corporate governance index composed on the basis of indicators regarding the audit committee, board of directors' size and structure, management competencies, they conclude that corporate governance influences significantly the company's performance, computed as ROE, ROA and net profit margin.

A similar study that use the VAR methodology based on panel data is made by the authors Kang, Germann, and Grewa (2016) who follow the implications of social responsibility on performance, and also, the study of Wang, Xiao and Xiao (2016) who track five performance indicators, such as: dividend per unit, return on equity, market value against book value, gross income on managed assets, and dividend yield through a VAR.

\section{Corporate Governance in Romania}

Corporate governance appears in our country, from a conceptual and regulatory point of view, only at the beginning of the 2000s. The delay is explained through the difficult steps taken in the field of political, legal, economic and social reforms. Governmental policies to liberalize the economy after the anticommunist revolution are lagging behind even after a decade of semi-capitalism. There is almost no strategy for the development of the sectors that could valorize the traditions and human and technological resources of Romanian society. The Bucharest Stock Exchange marks its first transactions since 1995. The Securities Commission fulfills its mission of supervising the circulation of values in a doubtful manner.

Therefore, Romania is an interesting case to be analyzed because the term of corporate governance has only been known since 2000 when factors such as the entry of foreign 
investors on the market or privatizations have stimulated the economy and have also contributed to the creation of new efforts for better practices of corporate governance.

In Romania, the code of corporate governance used by companies whose shares are traded on the regulated market is the Corporate Governance Code of the Bucharest Stock Exchange. This code was originally issued in 2001 and then revised and improved in 2008. Also, in September 11, 2015, a revised version of the code was published in order to take into account the knowledge assimilated during the period of crisis and great bankruptcies and also to comply with the standards of the European Union and, implicitly, Romania. The purpose of this Code is to encourage a strong and effective relationship between shareholders and stakeholders of the company, as well as to ensure transparent communication between these parties.

The Bucharest Stock Exchange operates with the "apply or explain" principle, through which specific and accurate information is provided to the public about the compliance of corporate governance principles by listed companies. The code is grouped in several levels, including the following: the main responsibilities of the listed companies, the risk management and internal control system, fair reward and motivation as well as the added value brought by the relations with investors.

\section{Research Methodology}

In order to measure the impact that the composed index of corporate governance has on performance, we started from the hypothesis that a company that has adopted and implemented the corporate governance $\operatorname{code}^{1}$ will have a higher financial performance than a company that has not adopted such a code, as well as a sustainable development, both in terms of total assets and profitability.

Therefore, to quantify the impact of corporate governance on the company's performance, we have developed an index of corporate governance (IGC) determined by applying a questionnaire to some companies representative in the energy sector. The questionnaire consists of 20 questions formulated according to the principles set out in the Corporate Governance Code of the Bucharest Stock Exchange, updated in September 2015. The questions are formulated in accordance with the stipulations that have to be respected for a good corporate governance, and cover the following sections: general information about the companies reviewed, the structure of the Board of Directors, the risk management system and the Audit Committee, as well as other relevant information for our research field. The questions are based on responses from public information disclosed by companies, such as company's annual reports, balance sheet and profit and loss account. The determination of the index value was made by summing the positive answers to the

\footnotetext{
${ }^{1}$ Corporate Governance Code of Bucharest Stock Exchange published in 11 September 2015.
} 
20 questions, being given to each positive answer 1 point and each negative answer 0 points. Therefore, the value of the index took values between 16 and 19 points, depending on the company's dimensions. In conclusion, we can say that a higher value of the index highlights a higher value of the company.

The composite index tracked the degree of compliance of the companies with the principles stipulated in the code of governance adopted by the Bucharest Stock Exchange. The results were centralized and reported to the maximum number of points, thus the index taking values between 0 and 1 depending on the degree of implementation of the principles of the corporate governance code. The results were centralized as a series of time, each industry being treated as a panel.

By taking into consideration the specificity of the energy sector, we used a Vector Auto Regression (VAR), taking into account also the causal relationship between performance and corporate governance, and more precisely the introduction of a set of principles stipulated in the Corporate Governance Code of Bucharest Stock Exchange.

\section{Data:}

The data used in the model were extracted from the public financial statements of the company's active in the Romanian energy system in for the period 2007 - 2015. The data were centralized from the financial statements of each company, namely: S.N.G.N. Romgaz S.A., Transgaz S.A., Lindegaz Romania S.R.L, S.P.E.E.H. Hidroelectrica S.A. And S.N. Nuclearelectrica S.A., being treated as a panel.

The main variables of the model are: company size, calculated as logarithm of the total asset, $\mathrm{ROA}^{2}$, general liquidity ${ }^{3}$, indebtedness level and corporate governance index.

\section{Model:}

The model used is an unrestricted VAR since the variables used are integrated with different orders.

${ }^{2}$ ROA $=$ Net Profit $/$ Total Assets $* 100$

${ }^{3}$ General Liquidity $=$ Current Assets $/$ Short Term Debts 


$$
\begin{aligned}
R O A_{1, t}=\alpha_{2} & +\Delta \sum_{j=1}^{j} \beta_{1, j} I G C_{1, t-j}+\Delta \sum_{j=1}^{j} \delta_{1, j} R O A_{1, t-j}+\Delta \sum_{k=1}^{k} \varepsilon_{1, j} L G_{1, t-j}+\Delta \sum_{k=1}^{k} \epsilon_{1, j} G I_{1, t-j} \\
& +\Delta \sum_{k=1}^{k} \theta_{1, j} T A_{1, t-j}+u 1_{t}
\end{aligned}
$$

Where:

$\mathrm{ROA}=$ return on assets / profitability

$I C G=$ corporate governance index

$L G=$ general liquidity

$\mathrm{HI}=$ indebtedness level

$\mathrm{TA}=$ company size expressed as total assets

$$
\begin{aligned}
T A_{1, t}=\alpha_{2}+ & \Delta \sum_{j=1}^{j} \beta_{1, j} I G C_{1, t-j}+\Delta \sum_{j=1}^{j} \delta_{1, j} R O A_{1, t-j}+\Delta \sum_{k=1}^{k} \varepsilon_{1, j} L G_{1, t-j}+\Delta \sum_{k=1}^{k} \epsilon_{1, j} G I_{1, t-j} \\
& +\Delta \sum_{k=1}^{k} \theta_{1, j} T A_{1, t-j}+u 1_{t}
\end{aligned}
$$

The number of Lags chosen is 1 as results from Table no. 1 .

VAR satisfies the condition of stability, as it results from Table no. 2, the condition regarding autocorrelation, as it results from the Table no. 3 , and the condition of heteroscedasticity according to the Table no. 4. 
Table no. 1 Selection of the optimal number of lags

\begin{tabular}{|c|c|c|c|c|c|c|}
\hline Lag & LogL & LR & FPE & AIC & SC & HQ \\
\hline 0 & 155.2708 & NA & 0.03006 & 10.68472 & 10.91825 & 10.75943 \\
\hline 1 & 12.73131 & 268.8033* & $2.24 \mathrm{e}-06^{*}$ & 1.151246* & 2.552443* & $1.599501^{\star}$ \\
\hline 2 & 35.84278 & 29.27453 & $2.95 \mathrm{E}-06$ & 1.277148 & 3.84601 & 2.098949 \\
\hline 3 & 53.01349 & 16.026 & 7.69E-06 & 1.7991 & 5.535627 & 2.994447 \\
\hline \multicolumn{7}{|c|}{${ }^{*}$ indicates lag order selected by the criterion } \\
\hline \multicolumn{7}{|c|}{ LR: sequential modified LR test statistic (each test at $5 \%$ level) } \\
\hline \multicolumn{7}{|c|}{ FPE: Final prediction error } \\
\hline \multicolumn{7}{|c|}{ AIC: Akaike information criterion } \\
\hline \multicolumn{7}{|c|}{ SC: Schwarz information criterion } \\
\hline
\end{tabular}

Source: own processing

Table no. 2 Assuring the VAR stability

\begin{tabular}{|c|c|}
\hline \multicolumn{1}{|c|}{ Root } & \multicolumn{1}{c|}{ Modulus } \\
\hline \hline 0.973738 & 0.973738 \\
\hline $\begin{array}{l}0.830848- \\
0.089874 \mathrm{i}\end{array}$ & 0.835695 \\
\hline $\begin{array}{l}0.830848+ \\
0.089874 \mathrm{i}\end{array}$ & 0.835695 \\
\hline
\end{tabular}




\begin{tabular}{|c|r|}
$\begin{array}{l}0.700889- \\
0.067629 i\end{array}$ & 0.704144 \\
\hline $\begin{array}{l}0.700889+ \\
0.067629 i\end{array}$ & 0.704144 \\
\hline \multicolumn{2}{|c|}{ No root lies outside the unit } \\
circle. \\
\hline \multicolumn{2}{|c|}{ VAR satisfies the stability } \\
condition.
\end{tabular}

Source: own processing

Table no. 3 Compliance with the autocorrelation conditions of the Portmanteau test

\begin{tabular}{|r|r|l|l|l|l|}
\hline Lags & Q-Stat & Prob. & $\begin{array}{c}\text { Adj Q- } \\
\text { Stat }\end{array}$ & Prob. & df \\
\hline 1 & 29.04448 & NA $^{*}$ & 29.78921 & NA $^{*}$ & NA* $^{*}$ \\
\hline 2 & 39.678 & 0.0315 & 40.98238 & 0.0231 & 25 \\
\hline *The test is valid only for lags larger than the VAR lag \\
order.
\end{tabular}

Source: own processing

Table no. 4 Result of the heteroscedasticity test

\begin{tabular}{|c|l|l|}
\hline \multicolumn{3}{|c|}{ Joint test: } \\
\hline Chi-sq & df & Prob. \\
\hline 181.4285 & 150 & 0.041 \\
\hline
\end{tabular}

Source: own processing 


\section{Accumulated Response of ROA to Cholesky One S.D. IGC Innovation}

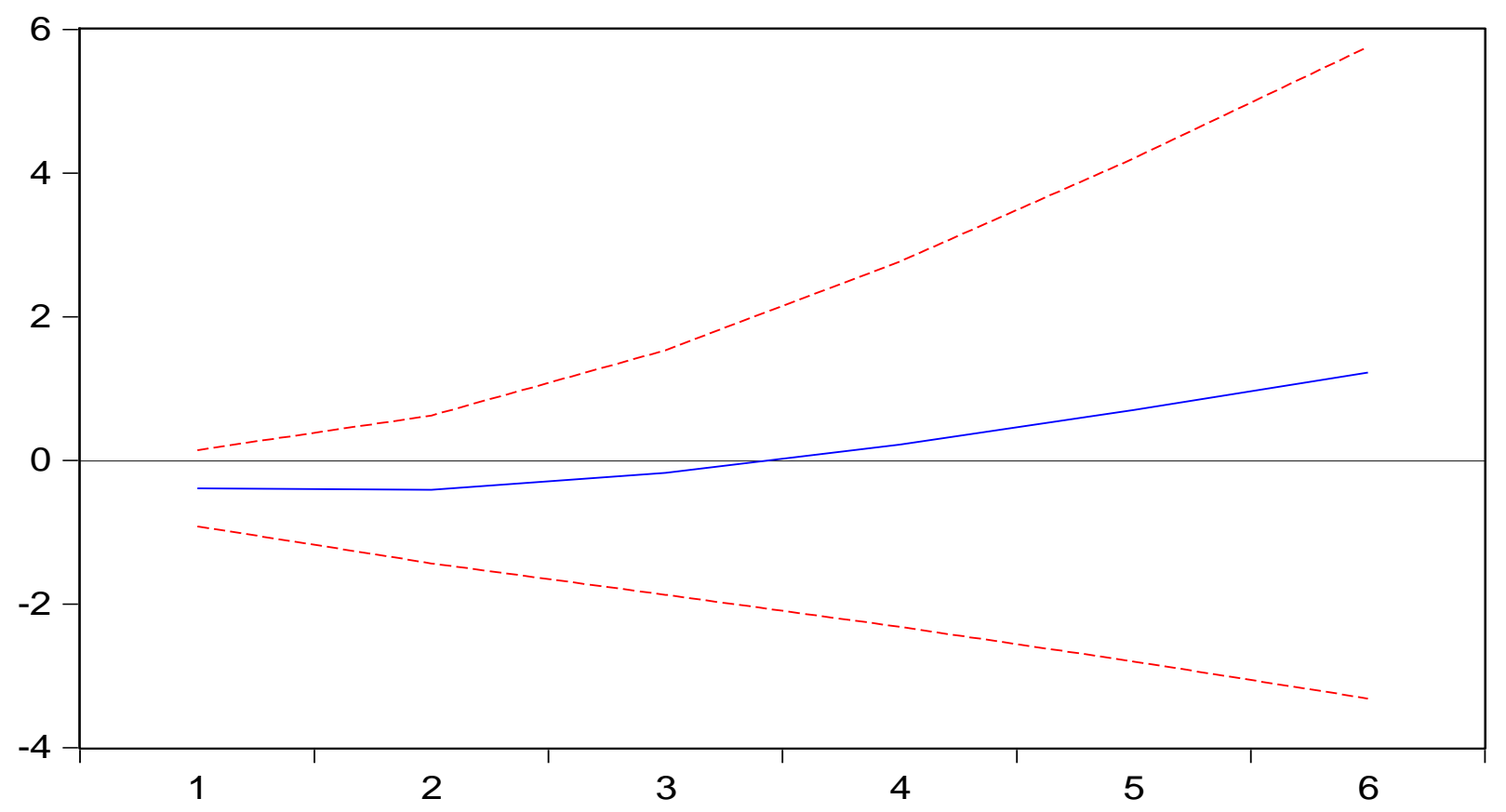

Chart no. 1 Impact of Corporate Governance Index on profitability

Source: own processing

In the Chart no. 1 we can observe a negative impact on profitability of the corporate governance index of companies in the energy system, following a downward trend, but in the last three years of the observation period the impact is positive, with a further improving trend. This confirms the opinions expressed in the specialized literature and the hypothesis of our research that good corporate governance positively influences the long-term profitability of the company. In conclusion, under the conditions of well-implemented corporate governance that complies with the principles of the Corporate Governance Code of the Bucharest Stock Exchange, we can observe a positive impact on the profitability of the company. 


\section{Accumulated Response of L_TA to Cholesky One S.D. IGC Innovation}

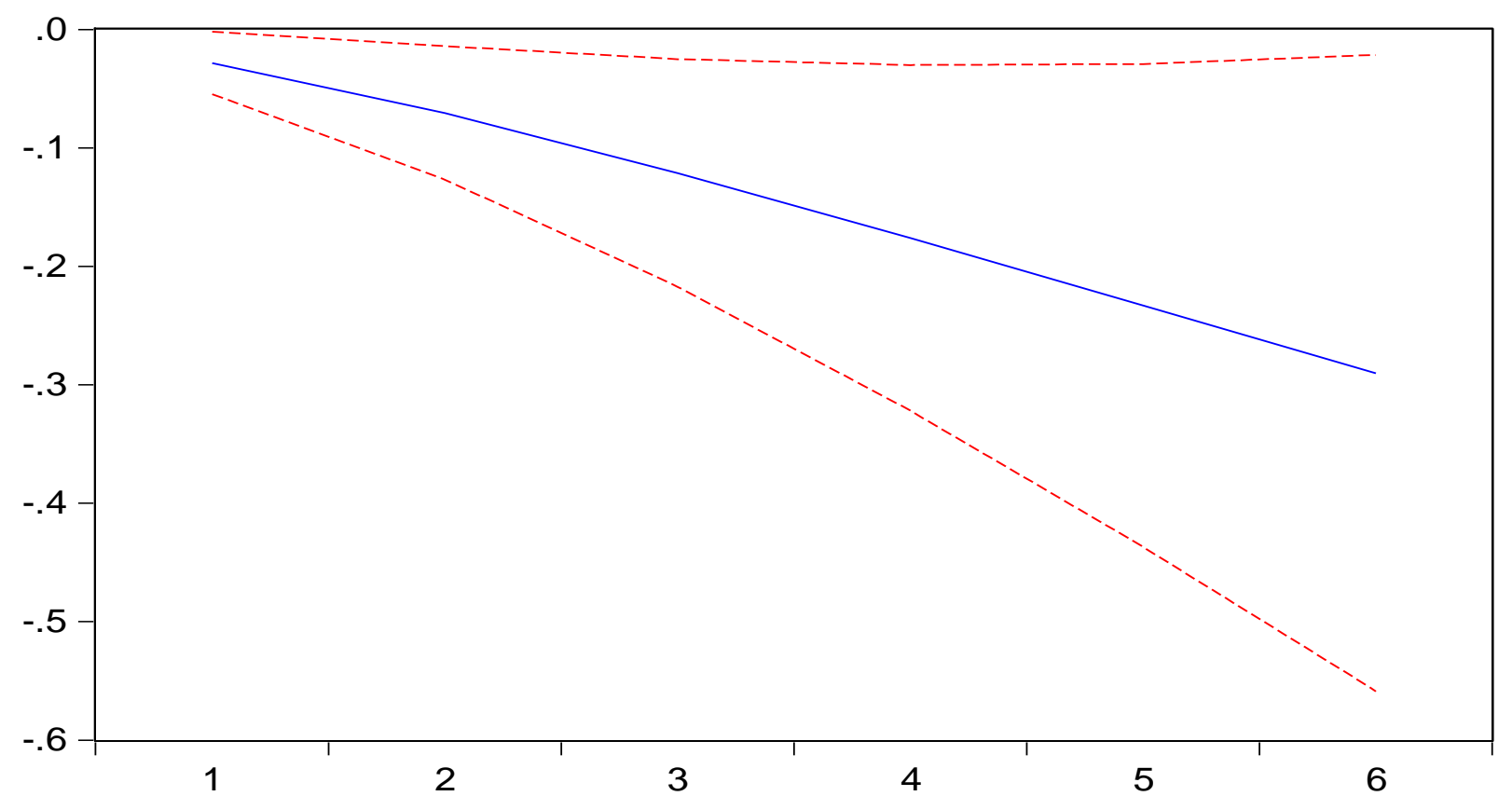

Chart no. 2 Impact of Corporate Governance Index on the company size

Source: own processing

Chart no. 2 shows a negative impact of the corporate governance index on the company's size in the Romanian energy system, on a downward trend over the entire observation period of six years. This impact may be due to one of the companies presented in our research, Hidroelectrica, which has been in insolvency for 4 years, undergoing a radical process of restructuring and efficiency. The most important measure taken during the insolvency period was the termination of bilateral contracts concluded with several energy traders, since the main reason for the insolvency mentioned in the Administrators' Report was the long period over which the contracts were concluded, for more than 10 years, without the possibility of modifying the contractual conditions. Therefore, we can conclude that the corporate governance index had a negative impact on the size of the company in the energy system, a result that was also influenced by the insolvency period of one of the companies analyzed. 


\section{Accumulated Response of LG to Cholesky \\ One S.D. IGC Innovation}

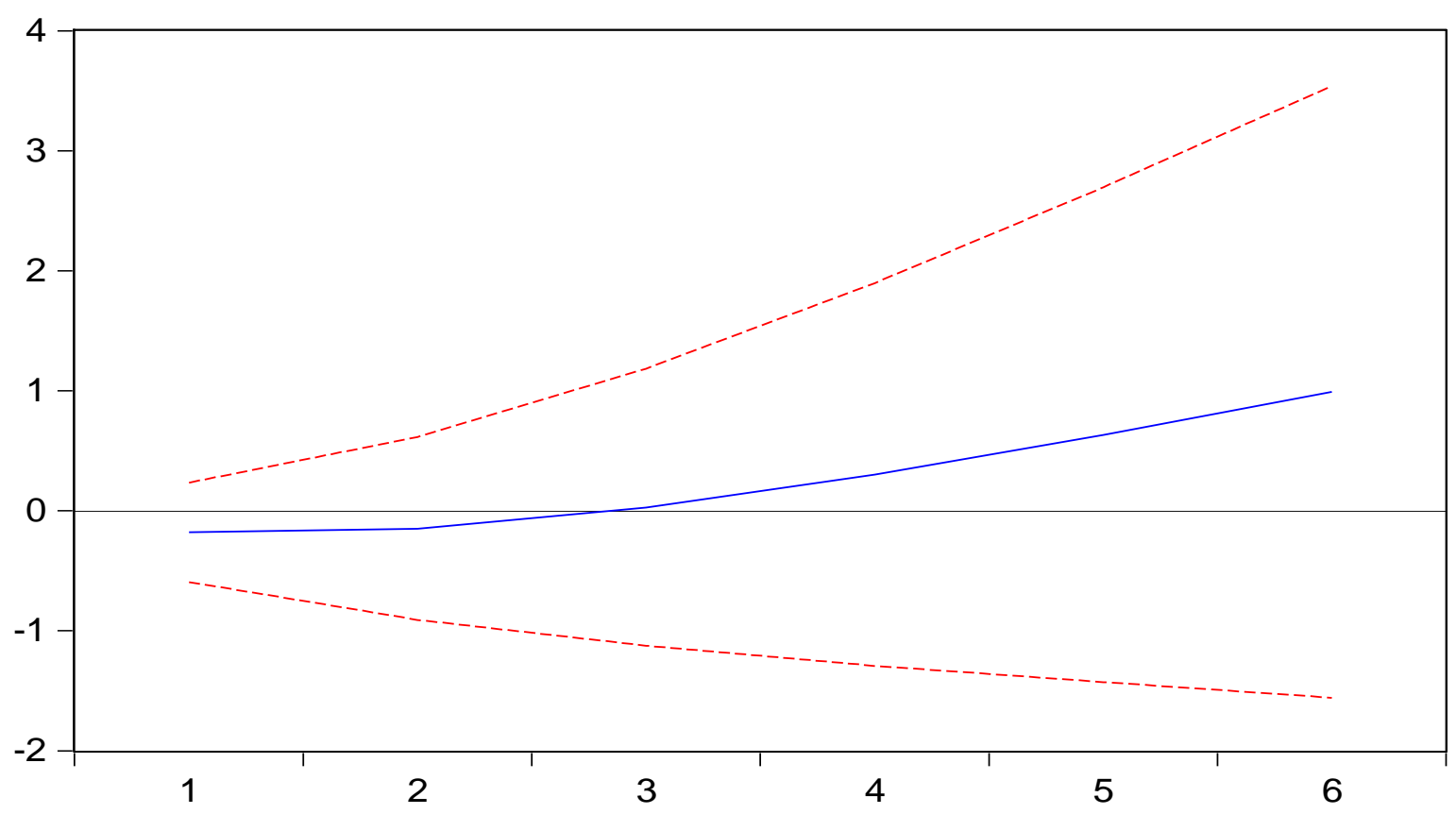

Chart no. 3 Impact of Corporate Governance Index on general liquidity

Source: own processing

In Chart no. 3 there is a positive impact of the corporate governance index on general liquidity in the Romanian energy system, on an ascending trend over the entire observation period of 6 years. A higher liquidity ratio demonstrates the ability of companies to pay their short-term payment obligations and also a lower default risk, which is reflected in the improvement of companies' performance. Therefore, with the effective implementation of corporate governance, we expect an increase in the company's overall liquidity and, implicitly, an increase in the company's performance. 


\section{Accumulated Response of GI to Cholesky One S.D. IGC Innovation}

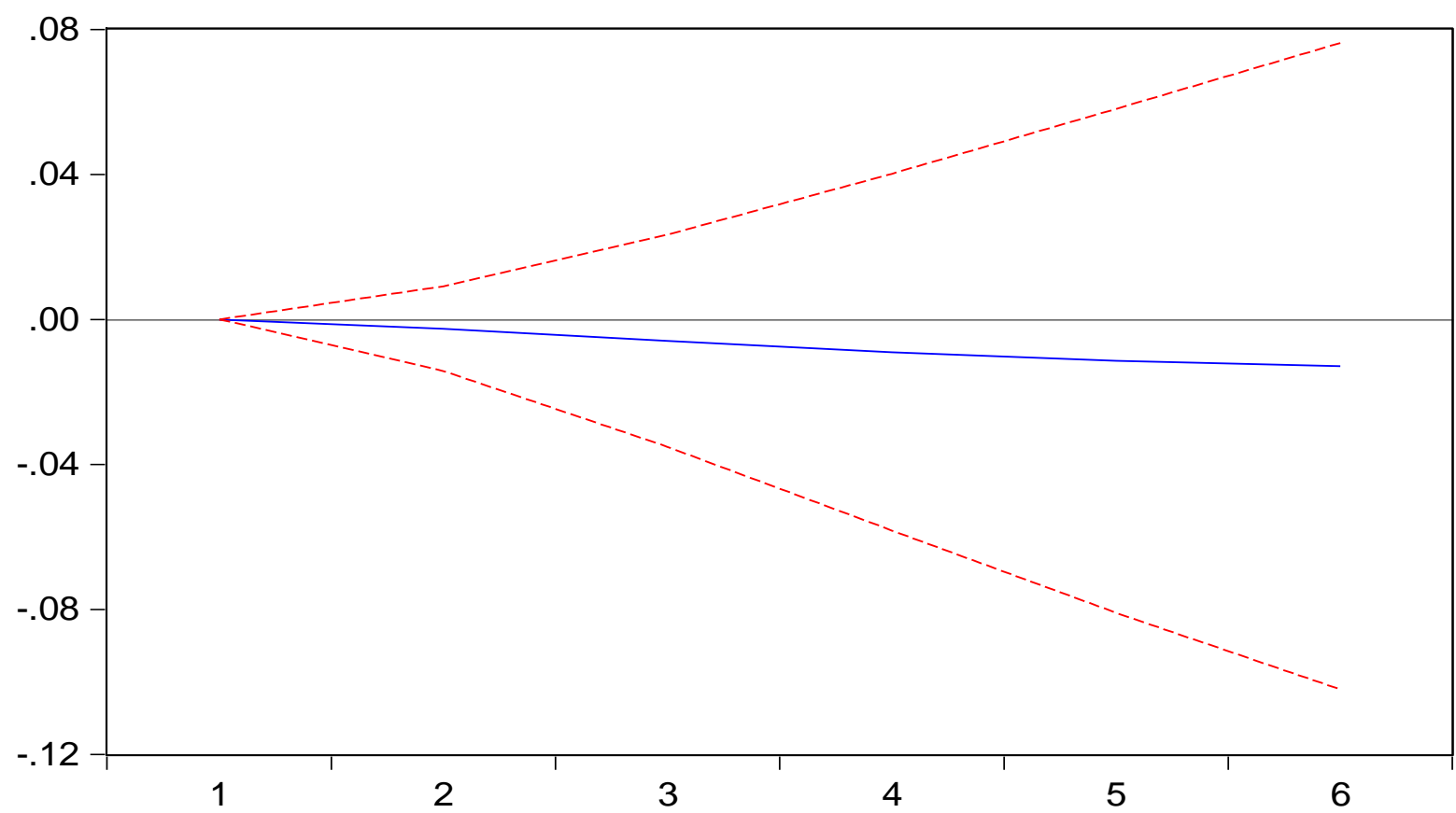

Chart no. 4 Impact of Corporate Governance Index on indebtness level Source: own processing

From Chart no. 4 we can observe that the corporate governance index has a negative impact on the indebtedness degree of companies active in the Romanian energy system, with growth tendencies, for the entire analyzed period of 6 years. A higher indebtedness rate highlights a high level of risk in terms of funding policies. Therefore, we can conclude that the impact of the corporate governance index is to mitigate an increase in corporate indebtedness, which is beneficial to the company, both in the long run and in the short term.

Table no. 5 Decomposition of ROA variance

\begin{tabular}{|r|c|c|c|c|c|c|}
\hline Period & S.E. & GI & IGC & L_TA & LG & ROA \\
\hline \hline 1 & 0.056254 & 35.84338 & $\mathbf{3 . 4 0 2 4 5 7}$ & 0.921381 & 0.033846 & 59.79894 \\
\hline 2 & 0.069364 & 42.80622 & $\mathbf{1 . 9 3 4 2 7 7}$ & 1.010712 & 0.22115 & 54.02765 \\
\hline
\end{tabular}




\begin{tabular}{|r|r|r|r|r|r|l|}
\hline 3 & 0.075346 & 47.6649 & $\mathbf{1 . 9 5 0 4 4 7}$ & 1.053102 & 0.508444 & 48.82311 \\
\hline 4 & 0.078346 & 50.79845 & $\mathbf{2 . 7 9 6 1 2 2}$ & 1.06426 & 0.851906 & 44.48926 \\
\hline 5 & 0.079929 & 52.68698 & $\mathbf{3 . 9 9 6 5 1 7}$ & 1.057487 & 1.214654 & 41.04436 \\
\hline 6 & 0.080811 & 53.74415 & $\mathbf{5 . 2 6 0 4 3 3}$ & 1.042054 & 1.570131 & 38.38324 \\
\hline \multicolumn{6}{|c|}{ Cholesky Ordering: GI IGC L_TA LG ROA } \\
\hline \hline
\end{tabular}

Source: own processing

As it can be observed in the Table no. 5, the impact of the corporate governance index explains $3.4 \%$ of the ROA variation in the first year of observation, reaching in the 6th observation year at a $5.2 \%$ explanation of the ROA variation. During the analysis period, the impact of the index had a downward trend in the $2^{\text {nd }}$ and $3^{\text {rd }}$ year, and starting with the $4^{\text {th }}$ year it began to explain the ROA variation. In this respect, the one-period lag shows the decrease from $3.4 \%$ to $1.9 \%$.

Table no. 6 Decomposition of total assets variance

\begin{tabular}{|r|l|l|l|l|l|l|}
\hline Period & S.E. & GI & IGC & L_TA & LG & ROA \\
\hline \hline 1 & 0.056254 & 27.59177 & $\mathbf{7 . 8 9 1 1 6 1}$ & 64.51707 & 0 & 0 \\
\hline 2 & 0.069364 & 21.76621 & $\mathbf{1 3 . 4 8 9 6 1}$ & 64.19209 & 0.541685 & 0.01041 \\
\hline 3 & 0.075346 & 17.36684 & $\mathbf{1 8 . 4 7 5}$ & 62.60944 & 1.528482 & 0.020235 \\
\hline 4 & 0.078346 & 14.14976 & $\mathbf{2 2 . 4 8 1 0 6}$ & 60.63393 & 2.708807 & 0.026431 \\
\hline 5 & 0.079929 & 11.81086 & $\mathbf{2 5 . 5 3 4 3 7}$ & 58.70335 & 3.921416 & 0.029995 \\
\hline 6 & 0.080811 & 10.09808 & $\mathbf{2 7 . 7 9 5 1 6}$ & 56.99613 & 5.078333 & 0.032291 \\
\hline \multicolumn{7}{|c|}{ Cholesky Ordering: GI IGC L_TA LG ROA } \\
\hline \hline
\end{tabular}

Source: own processing 
As shown in Table no. 6, the impact of the corporate governance index explains $7.89 \%$ of the total assets variation in the first year of research, reaching in the $6^{\text {th }}$ year of observation at an explanation of $27.79 \%$ of the total assets variation. In this respect, the one-period lag shows the increase from $7 \%$ to $13 \%$ (lag 1 and lag 2 ).

\section{Conclusions}

As a conclusion of the study performed in the Romanian energy system, we noticed a slightly negative impact of the corporate governance index on profitability, with a significant improvement trend over the period analyzed, which confirmed both the specialized literature in the field and the research hypothesis that we set ourselves. Thus, with the efficient implementation of corporate governance within the energy system, which fully respects the principles set out in the Corporate Governance Code of the Bucharest Stock Exchange, it can be observed a positive impact on the long-term profitability of the company.

Also, in our research, we noticed a negative impact of the corporate governance index over the company's size in the Romanian energy system, which in our view is mainly due to the insolvency of one of the analyzed companies, Hidroelectrica that has undergone a radical restructuring and streamlining process for 4 years.

On the other hand, the corporate governance index has a positive impact on liquidity in the Romanian energy system over the entire analyzed period, which demonstrates the ability of companies to pay their short-term payment obligations as well as a lower risk of nonpayment. In conclusion, the implementation of a corporate governance code in the Romanian energy system will generate an increase in the overall liquidity of companies, which in turn will contribute to an increase in companies' performance.

The research also proved a negative impact of the corporate governance index on the indebtedness of companies in the Romanian energy system. Considering a relationship of direct proportionality between indebtedness level and funding risk, we can conclude that the corporate governance index contributes to mitigate this risk, an impact that has a positive influence on companies, both on long and short term.

In conclusion, our research reveals the necessity to continuously adapt the corporate governance code to the financial realities present on the Romanian economic market. 


\section{Appendices}

\section{Annex no. 1. Perceptual Investigation Questionnaire on corporate governance of the company}

This questionnaire is designed to assess the perception of respondents on the quality of financial reporting as a means of financial communication.

\section{General Information}

1. Is the company listed on the Bucharest Stock Exchange?

a) YES;

b) NO.

2. Is the company part of an international corporation?

a) YES;

b) NO.

3. Does the company or "parent company" have a corporate governance code?

a) YES;

b) NO.

4. Does the company submit the financial statements to the data provided by the Romanian legislation in force?
a) YES;
b) NO.

5. Does the company use international accounting standards (IFRS, IAS or US GAAP)?
a) YES;
b) NO.

6. Is the company audited by one of the companies in BIG4 (Ernst \& Young, Deloitte, KPMG and PricewaterhouseCoopers)?
a) YES;
b) NO.

\section{Structure of the Board of Directors}


7. Is there a clear division of responsibilities between the Board of Directors and the executive management of the company?
a) YES;
b) NO.

8. Is the President of the Board of Directors the same person as the general manager of the company?
a) YES;
b) NO.

9. Does the Board of Directors consist of at least 5 members and no more than 9 members?
a) YES;
b) NO.

10. Is the Board of Directors composed only of company employees and majority shareholders?
a) YES;
b) NO.

11. Aren't the independent members of the Board of Directors employees of the company and have not held such a position in the last 5 years??
a) YES;
b) NO.

\section{Risk Management System and Audit Committee}

12. Does the company have a risk management and internal control system?
a) YES;
b) NO.

13. Does the Audit Committee consist of at least three members?
a) YES;
b) NO.

14. Does the Audit Committee have at least one member who is an independent, nonexecutive administrator?
a) YES;
b) NO. 
15. Does the Audit Committee have at least one member with relevant expertise and having relevant certifications in the field?
a) YES;
b) NO.

16. Is the Audit Committee responsible for the annual assessment of the internal control system?
a) YES;
b) NO.

17. Is the Audit Committee responsible for monitoring generally accepted internal audit standards?
a) YES;
b) NO.

\section{Other relevant information}

18. Does the Company have a policy of distributing dividends or other benefits to shareholders annually?
a) YES;
b) NO.

19. Are external auditors present at the Shareholders' General Assembly when their reports are presented at meetings?
a) YES;
b) NO.

20. Do the quarterly and half-yearly financial reports of the company include information on the company's financial indicators (operating profit, net profit, as well as other relevant company indicators) in both Romanian and English?
a) YES;
b) NO. 


\section{References}

Aguilera, R., Cuervo - Cazurra, A., Codes of good governance world - wide: what is the trigger?, Organization Studies, 2004, pp. 415-443.

Alley, I., Adebayo, A., Oligbi, B., Corporate Governance and Financial Performance Nexus: Any Bidirectional Causality?, International Journal of Management and Economics, No. 50, April-June 2016, pp. 82-99.

Black, B.S., Love, I., Rachinsky, A., Corporate Governance and Firms' Market Values: Time-Series Evidence from Russia, Working Paper, 2005.

Black, B.S., Jang, H., Kim W., Does Corporate Governance Predict Firms' Market Values? Evidence from Korea, Journal of Law, Economics and Organization, vol. 22, 2006a, pp. 366-413.

Da Silva, C., Luiz, A, Pereira, C. L., Corporate Governance Index, Firm Valuation and Performance in Brazil, Revista Brasiliera de Financas, Vol. 3, 2005, pp. 1 - 18.

Doidge, C.A., Karolyi, G.A., Stulz R.M., Why Do Countries Matter so Much for Corporate Governance?, Working Paper, European Corporate Governance Institute, 2004.

Durnev, A., Kim, E.H., To Steal or Not to Steal: Firm Attributes, Legal Environment, and Valuation, Journal of Finance, 60, 2005, pp. 1461-1493.

Gillan, S.L., Hartzell, J.C., Starks L.T., Explaining Corporate Governance: Boards, Bylaws, and Charter Provisions, Working paper, University of Texas, McCombs, 2003.

Grove, H., Patelli, L., Victoravich, L., Xu P., Corporate Governance and Performance in the Wake of the Financial Crisis: Evidence from US Commercial Banks, Corporate Governance: An International Review, 2011, 19(5): 418-436.

Kang, C., Germann, F., Grewa, R., Washing Away Your Sins? Corporate Social Responsibility, Corporate Social Irresponsibility and Firm Performance, Journal of Marketing, 80 (2), 59-79.

Klapper, L.F., Love, I., Corporate Governance, Investor Protection, and Performance in Emerging Markets, Journal of Corporate Finance. 10, 2004, pp. 287-322.

Kouwenberg, R., Does Voluntary Corporate Governance Code Adoption Increase Firm Value in Emerging Markets? Evidence from Thailand, College of Management, Mahidol University, November 2006.

Reddy, K., Locke S., Scrimgeour, F., The efficacy of principle-based corporate governance practices and firm financial performance - An empirical investigation, International Journal of Managerial Finance, Vol. 6 No. 3, 2010, pp. 190-219

Wang, X., Xiao, X., Xiao, Z., S-Reits' Performance Forecast Using a Small Sample Model Associating Support Vector Machine with Vector Auto-Regression Model, International Journal of Innovative Computing, Volume 12, Number 1, February 2016. 